\title{
INVESTMENT OF CHARACTER VALUES CARE ENVIRONMENT IN LEARNING SCIENCE SOCIAL KNOWLEDGE BASED AUDIO VISUAL
}

\section{Yonaka Adventa}

Universitas Sebelas Maret

yonaka.adventa@gmail.com

\section{Article History}

accepted 09/07/2018

approved 01/08/2018

published 17/09/2018

\section{Keywords}

Environmental Character Values, Social Science Learning, Audio, Visual Media

\begin{abstract}
Education is one important element in changing the life of society. Character education plays a role in shaping the personality of the younger generation. One of the values of character that is not less important to be cultivated to peseta students educate the environment. Through learning social science can include the values of character education by integrating the material in social science learning. Here learners love the environment more in a simple way like throwing garbage in place, taking care of plants, cleaning the environment. To support the learning of Social Sciences then a teacher uses the aid of audio visual learning media so that learners are able to understand the value of environmental care characters. This conceptual article as an insight in instilling the value of environmental caring character in Social Science learning through audio visual media.
\end{abstract}

Social, Humanities, and Education Studies (SHEs): Conference Series https://jurnal.uns.ac.id/shes

p-ISSN 2620-9284 e-ISSN 2620-9292 


\section{PENDAHULUAN}

Di era ini menuntut masyarakat untuk terus berkembang dan membuat inovasiinovasi yang baru agar dapat bertahan. Masyarakat perlu merubah pola pemikiran dan berusaha beradaptasi dengan lingkungan, dimana perkembangan di era ini di tandai dengan kemajuan teknologi dan informasi yang begitu cepat sehingga membuat masyarakat harus bisa menyesuaikan diri.

Permasalahan lingkungan yang selama ini tejadi harus segera ditanggulangi. Salah satu upaya untuk mengatasi permasalahan lingkungan yaitu melalui pembentukan karakter peduli lingkungan sejak dini. Dikti (Hamzah B. Uno dan Nurdin Mohamad, 2011:136) mengemukakan bahwa menyadarkan masyarakat yang sudah terlanjur kurang memahami arti kualitas lingkungan untuk kelestarian umat manusia, sulit dilakukan. Lebih lanjut lagi menurut Hamzah B. Uno dan Nurdin Mohamad (2011:136) menyebutkan bahwa penanamaman, pemahaman, dan kesadaran tentang pentingnya menjaga kelestarian kualitas lingkungan sangat baik apabila mulai diterapkan melalui pendidikan. Pendidikan yang paling dasar yaitu sekolah dasar. Pada masa usia sekolah ini menurut Uyoh Sadulloh (2010:141) menyebutkan bahwa anak sangat aktif mempelajari apa saja yang ada di lingkungannya, dorongan untuk mengetahui dan berbuat terhadap lingkungannya sangat besar. Penanaman karakter sejak dini dapat menjadi dasar yang kuat bagi anak.

Karakter yang baik terdiri dari mengetahui hal yang baik, menginginkan hal yang baik, dan melakukan hal yang baik kebiasaan dalam cara berfikir, kebiasaan dalam hati dan kebiasaan dalam bertindak. Ketiga hal ini diperlukan untuk mengarahkan suatu kehidupan, ketiga hal ini membentuk kedewasaan moral, ketika kita berfikir tentang jenis karakter yang kita inginkan bagi anak-anak kita, sudah jelas bahwa kita menginginkan anak-anak kita untuk mampu menilai apa yang benar, sangat peduli tentang apa yang benar, kemudian melakukan apa yang mereka yakini itu benar meskipun berhadapan dengan godaan dari dalam dan tekanan luar. (Thoms Lickona, $2011: 81-82)$

Salah satu karakter yang tidak kalah penting untuk ditanamkan pada diri peserta didik sejak dini adalah peduli terhadap lingkungan. Nilai karakter tersebut berupa sikap dan tindakan yang selalu berupaya mencegah kerusakan lingkungan alam sekitarnya. Selain itu juga upaya-upaya untuk memperbaiki kerusakan alam yang sudah terjadi dan selalu ingin memberi bantuan bagi orang lain dan masyarakat yang membutuhkan. (Jamal Ma'mur Asmani, 2013 : 9-10).

Penanaman nilai karakter peduli lingkungan dapat ditanamkan berdasarkan kurikulum sekolah maupun program-program yang sudah direncanakan sekolah. Untuk menunjang guru dalam menanamkan nilai karakter maka dalam dunia pendidikan sudah mengalami tuntutan perkembangan teknologi informasi khususnya dalam bidang pembelajaran. Tuntutan tersebut adalah usaha untuk meningkatkan mutu pendidikan. Pembelajaran yang berbasis teknologi informasi adalah pembelajaran dengan menggunakan perangkat atau media. Namun yang menjadi permasalahan adalah belum semua teknologi bisa diterapkan dalam pembelajaran karena penyebaran teknologi yang belum merata. Disisi lain beberapa guru belum bisa untuk mengoperasikan media yang berbasis teknologi.

Pembelajaran berbasis teknologi sebenarnya dapat menunjang tercapainya tujuan dari pembelajaran, karena peserta didik dapat menumbuhkan motivasi semangat untuk belajar. Tidak hanya menumbuhkan motivasi dengan pemanfaatan teknologi peserta didik dapat menambah wawasan dari berbagai sumber, kemudahan dalam mencari informasi, kualitas pembelajaran dapat ditingkatkan.

Berbagai dampak dari kemajuan bangsa ini terhadap moralitas anak sangat kurang, diperlukan perhatian dan pengawasan dari berbagai pihak, agar dalam proses tumbuh kembang anak selanjutnya tidak menimbulkan hal-hal yang merugikan, bagi bagi anak tersebut, keluarga ataupun sebagai warga negara. Disini Perhatian dan 
pengawasan orang tua dan berbagai pihak sangatlah penting. Terutama adalah peran seorang guru di sekolah dalam menanamkan pendidikan karakter di usia emas.

Merosotnya perkembangan lingkungan saat ini pada menuntut para pendidik dalam menanamkan nilai karakter sejak dini. Menumbuhkan nilai karakter peduli lingkungan dapat mengatasi perubahan pola pikir terhadap lingkungan. Untuk menanamkan nilai karakter tersebut dapat melalui media audio visual dalam membantu pendidik dalam pembelajaran. Dari latar belakang diatas maka artikel ini dibuat oleh peneliti untuk mengetahui pentingnya penanaman nilai karakter peduli lingkungan pada pembelajaran IPS melalui media audio visual

\section{METODE}

Metode yang digunakan dalam artikel ini adalah literature review. Literature review adalah uraian tentang teori, temuan dan bahan penelitian yang diperoleh dari bahan acuan dan dapat dijadikan landasan penelitian. Menurut Watts (2011: 308) artikel konseptual adalah artikel yang menghasilkan perspektif baru, prosedur atau teknik inovasi baru, membahas isu-isu profesi yang sedang terjadi, menyampaikan posisi penulis terhadap suatu isu bidang profesi, ataupun menyampaikan reaksi atau respon terhadap publikasi artikel sebelumnya. Dalam APA, (2010: 10) artikel teoritis atau konseptual menyajikan informasi empiris karena relevan dengan pengembangan atau evaluasi dari teori. Artikel teoritis menelusuri perkembangan teori untuk memperluas dan menyempurnakan konstruksi teoritis atau menyajikan teori baru atau menganalisis teori yang ada, menunjukkan kekurangan atau menunjukkan keuntungan dari satu teori di atas yang lain.

\section{PEMBAHASAN}

\section{Pendidikan Karater}

Karakter berasal dari bahasa Yunani Kharakter yang berakar dari diksi “ kharassein" yang berarti memahat atau mengukir (to incribe/to engrave), sedang dalam bahasa Latin, karakter bermakna membedakan tanda. Dalam kamus Inggris-Indonesia, John M. Echols dan Hassan S menyebutkan bahwa karakter berasal dari bahasa Inggris yaitu character yang verarti watak, karakter atau sifat.

Karakter berarti tabiat atau kepribadian seseorang. Coon (Zubaedi, 2011: 8) mendefinisikan karakter sebagai suatu penilaian subjektif terhadap kepribadian seseorang yang berkaitan dengan atribut kepribadian yang dapat atau tidak dapat diterima masyarakat. Karakter merupakan keseluruhan kodrati dan disposisi yang telah dikuasai secara stabil yang mendifinisikan seseorang individu dalam keseluruhan tata perilaku psikisnya yang menjadikan tipikal dalam cara berfikir dan bertindak. Doni Koesoema mengutip Sjarkawi, menyatakan bahwa karakter juga sering diasosiasikan dengan istilah apa yang disebut dengan temperamen yang lebih memberi penekanan pada definisi psikososial (pemahaman seorang individu atas situasi sosial di lingkungannya) yang dihubungkan dengan pendidikan dan konteks lingkungan. Sedangkan karakter dilihat dari sudut pandang behaviorial lebih menekankan pada unsur somatopsikis (penyakit fisik yang disebabkan oleh kejiwaan) yang dimiliki seseorang sejak lahir. Elfindri dkk mengartikan karakter sebagai sifat-sifat kejiwaan, akhlak, atau budi pekerti yang membedakan seseorang dengan orang lain. Kemudian Elfindri dkk mengklasifikasikan karakter pada empat bagian; karakter lemah, karakter kuat, karakter jelek dan karakter baik. Masing-masing dapat dilihat dengan indikator karakter sebagai berikut: (1) Karakter lemah dapat ditemukan seperti; penakut, tidak berani mengambil resiko, pemalas, cepat kalah, dan beberapa jenis lainnya. (2)Karakter kuat dapat ditemukan seperti; tangguh, ulet, mempunyai daya juang yang kuat serta pantang mengalah. (3)Karakter jelek, misalnya; licik, egois, serakah, 
sombong, tinggi hati, pamer, suka ambil muka, dan sebagainya. (4) Karakter baik, misalnya; jujur, terpercaya, rendah hati, amanah dan sebagainya.

Dengan melihat klasifikasi dan indikator diatas, Elfindri dkk menyimpulkan bahwa karakter anak yang diharapkan adalah karakter yang kuat dan baik. Kualitas mental atau kekuatan moral, akhlak atau budi pekerti yang merupakan kepribadian khusus yang harus melekat.

Muclas Samani dan Hariyanto (2011: 46) menyatakan pendidikan karakter adalah upaya terencana menjadikan peserta didik mengenal, peduli, dan mengiternalisasikan nilai-nilai sehingga peserta didik berperilaku sebagai insan kamil. Mulyasa (2011: 9) berpendapat pendidikan karakter menekankan pada keteladanan, penciptaan lingkungan, dan pembiasaan. Pendidikan karakter mempunyai tingkatan yang lebih tinggi dengan pendidikan budi perkerti. Hal ini ditunjukan dengan ruang lingkup pelaksanaan yang tidak terbatas pada proses pembelajaran. Menurut Masnur Muslich (2011: 81) tujuan pendidikan karakter adalah "meningkatkan mutu penyelenggaraan dan hasil pendidikan yang mengarah pada pencapaian pembentukan karakter dan akhlak mulia peserta didik secara utuh, terpadu dan seimbang. melalui pendidikan karakter diharapkan peserta didik mampu secara mandiri meningkatkan dan menggunakan pengetahuannya, mengkaji dan menginternalisasikan, serta mempersonalisasikan nilai-nilai karakter dan akhlak mulia sehingga terwujud dalam perilaku sehari-hari".

Dalam Undang-Undang No. 20 tahun 2003 tentang Sistem Pendidikan Nasional merumuskan fungsi dan tujuan pendidikan nasional yang harus digunakan dalam mengembangkan upaya pendidikan di Indonesia. Pasal 3 UU Sisdiknas menyebutkan "Pendidikan nasional berfungsi mengembangkan kemampuan dan membentuk watak serta peradaban bangsa yang bermartabat dalam rangka mencerdaskan kehidupan bangsa, bertujuan untuk berkembangnya potensi peserta didik agar menjadi manusia yang beriman dan bertakwa kepada Tuhan Yang Maha Esa, berakhlak mulia, sehat, berilmu, cakap, kreatif, mandiri, dan menjadi warga negara yang demokratis serta bertanggungjawab".

Fungsi pendidikan karakter menurut Maswardi Muhammad Amin (2011:7), merupakan upaya menumbuh kembangkan kemampuan dasar peserta didik agar berfikir cerdas, berperilaku yang berakhlak, bermoral, dan berbuat sesuatu yang baik, yang bermanfaat bagi diri sendiri, keluarga, dan masyarakat (domain kognitif, afektif, dan psikomotorik), membangun kehidupan bangsa yang multikultural, membangun peradaban bangsa yang cerdas, berbudaya luhur, berkonstribusi terhadap pengembangan hidup umat manusia, membangun sikap warga Negara yang cinta damai, kreatif, mandiri, maupun hidup berdampingan dengan bangsa lain.

Menurut E. Mulyasa (2011:9), Pendidikan karakter bertujuan untuk meningkatkan mutu proses dan hasil pendidikan yang mengarah pada pembentukan karakter dan akhlak mulia peserta didik secara utuh, terpadu, dan seimbang, sesuai dengan standar kompetensi lulusan pada setiap satuan pendidikan. Melalui pendidikan karakter peserta didik diharapkan mampu secara mandiri meningkatkan dan menggunakan pengetahuannya, mengkaji dan menginternalisasikan serta mempersonalisasikan nilainilai karakter dan akhlak mulia sehingga terwujud dalam perilaku sehari-hari.

Penanaman nilai karakter bermanfaat sebagai keunggulan kepribadian bangsa yang akan datang. Penanaman nilai karakter merupakan usaha yang dilakukan bersama oleh lingkungan keluarga, lingkungan sekolah dan lingkungan masyarakat yang merupakan bagian yang tidak dapat dipisahkan. Pendidikan karakter sejalan dengan tujuan pendidikan IPS yaitu membina anak didik menjadi warga negara yang baik, yang memiliki pengetahuan, keterampilan dan kepedulian sosial yang berguna bagi dirinya sendiri serta bagi masyarakat dan bagi negara. Untuk merealisasikan tujuan tersebut, proses mengajar dan membelajarkannya, tidak hanya terbatas pada aspek-aspek pengetahuan (kognitif) dan keterampilan (psikomotor) saja, melainkan 
juga meliputi aspek akhlak (afektif) serta bertanggung jawab sesuai yang terkandung dalam nilai-nilai Pancasila.

Nilai-nilai karakter yang dijadikan sekolah sebagai nilai-nilai utama yang diambil/disarikan dari butir-butir standar kompetensi lulusan dan mata pelajaran yang ditargetkan untuk diinternalisasi oleh peserta didik. Tim Pendidikan Karakter Kemendiknas (2010: 9-10) nilai-nilai tersebut antara lain: (a.) Nilai karakter dalam hubungan dengan Tuhan (religius) Pikiran, perkataan, dan tindakan seseorang yang diupayakan selalu berdasarkan pada nilai-nilai ajaran agamanya. (b)Nilai karakter dalam hubungannya dengan diri sendiri (1) Jujur,Perilaku yang didasarkan pada upaya menjadikan dirinya sebagai orang yang selalu dapat dipercaya dalam perkataan, tindakan, dan pekerjaan, baik terhadap diri dan pihak lain. (2) Bertanggung jawab, Sikap dan perilaku seseorang untuk melaksanakan tugas dan kewajibannya sebagaimana yang seharusnya dia lakukan terhadap diri sendiri, masyarakat, lingkungan (alam, sosial dan budaya), negara dan Tuhan YME. (3) Bergaya hidup sehat, Segala upaya untuk menerapkan kebiasaan yang baik dalam menciptakan hidup yang sehat dan menghindarkan kebiasaan buruk yang dapat mengganggu kesehatan. (4) Disiplin,Tindakan yang menunjukkan perilaku tertib dan patuh pada berbagai ketentuan dan peraturan.(5)Kerja keras, Perilaku yang menunjukkan upaya sungguh-sungguh dalam mengatasi berbagai hambatan guna menyelesaikan tugas (belajar/pekerjaan) dengan sebaik-baiknya. (5)Percaya diri, Sikap yakin akan kemampuan diri sendiri terhadap pemenuhan tercapainya setiap keinginan dan harapannya. (6)Berjiwa wira usaha, Sikap dan perilaku yang mandiri dan pandai atau berbakat mengenali produk baru, menentukan cara produksi baru, menyusun operasi untuk pengadaan produk baru, memasarkannya, serta mengatur permodalan operasinya. (7)Berfikir logis, kritis, kreatif, dan inovatif, Berpikir dan melakukan sesuatu secara kenyataan atau logika untuk menghasilkan cara atau hasil baru dan termutakhir dari apa yang telah dimiliki. (8)Mandiri,Sikap dan perilaku yang tidak mudah tergantung pada orang lain dalam menyelesaikan tugas-tugas.(9)Ingin tahu,Sikap dan tindakan yang selalu berupaya untuk mengetahui lebih mendalam dan meluas dari apa yang dipelajarinya, dilihat, dan didengar. (10)Cinta ilmu,Cara berpikir, bersikap dan berbuat yang menunjukkan kesetiaan, kepedulian, dan penghargaan yang tinggi terhadap pengetahuan. (c)Nilai karakter dalam hubungannya dengan sesama antara lain : (1)Sadar akan hak dan kewajiban diri dan orang lain, Sikap tahu dan mengerti serta melaksanakan apa yang menjadi milik/hak diri sendiri dan orang lain serta tugas/kewajiban diri sendiri serta orang lain. (2)Patuh pada aturan-aturan sosial,Sikap menurut dan taat terhadap aturan-aturan berkenaan dengan masyarakat dan kepentingan umum. (3)Menghargai karya dan prestasi orang lain, Sikap dan tindakan yang mendorong dirinya untuk menghasilkan sesuatu yang berguna bagi masyarakat, dan mengakui dan menghormati keberhasilan orang lain. (4)Santun,Sifat yang halus dan baik dari sudut pandang tata bahasa maupun tata perilakunya ke semua orang.(5)Demokratis, Cara berfikir, bersikap dan bertindak yang menilai sama hak dan kewajiban dirinya dan orang lain.

Pentingnya pendidikan karakter dan nilai-nilai dasarkarakter perlu dikembangkan, pendidikan karakter untuk diberikan dalam proses pendidikan, yaitu seperti berdasarkan hasil penelitian Heckman, James \& Pedro Carneiro (2003) yang dikutip oleh Ratna Megawangi, menunjukkan bahwa kecerdasan intelektual seseorang (verbal dan logis-matematis) hanya memberikan kontribusi $20 \%$ saja dari keberhasilan seseorang di masyarakat, sedangkan $80 \%$ lebih banyak ditentukan oleh kecerdasan emosi seseorang tersebut. Kecerdasan emosi merujuk pada karakter atau dalam bahasa agamanya akhlak mulia. Penelitian tersebut sesuai dengan hasil penelitian George Boggs, yang juga disitir Ratna Megawangi yang menunjukkan bahwa dari 13 faktor penunjang keberhasilan seseorang di dunia kerja, 10 di antaranya (hampir $80 \%$ ) adalah kualitas karakter seseorang, dan sisanya (tiga) berkaitan dengan faktor 
kecerdasan intelektual. Ke-13 faktor tersebut adalah: (1) jujur dan dapat diandalkan; (2) bisa dipercaya dan tepat waktu; (3) bisa menyesuaikan diri dengan orang lain; (4) bisa bekerjasama dengan atasan; (5) bisa menerima dan menjalankan kewajiban; (6) mempunyai motivasi kuat untuk terus belajar dan meningkatkan kualitas diri; (7) berpikir bahwa dirinya berharga; (8) bisa berkomunikasi dan mendengarkan secara efektif; (9) bisa bekerja mandiri dengan supervisi minimum; (10) dapat menyelesaikan masalah pribadi dan profesinya; (11) mempunyai kemampuan dasar (kecerdasan); (12) bisa membaca dengan pemahaman memadai; dan (13) mengerti dasar-dasar matematika (berhitung).

Agar pendidikan karakter dapat berjalan secara komprehensif dalam proses pendidikan di sekolah, maka penerapan pendidikan karakter di sekolah perlu memegang prinsip-prinsip sebagai berikut: a. Berkelanjutan mengandung makna bahwa proses pengembangan nilai-nilai budaya dan karakter bangsa merupakan sebuah proses panjang dimulai dari awal peserta didik masuk sampai selesai dari suatu satuan pendidikan. b. Melalui semua mata pelajaran, pengembangan diri, dan budaya sekolah. c. Nilai tidak diajarkan tapi dikembangkan mengandung makna bahwa materi nilai-nilai budaya dan karakter bangsa bukanlah bahan ajar untuk pembelajaran biasa. d. Proses pendidikan dilakukan peserta didik secara aktif dan menyenangkan.

Berdasarkan dari beberapa diatas dapat disimpulkan bahwa pendidikan karakter adalah upaya dalam menanamkan serta mengembangkan moral dan ahlak seseorang baik dari pendidikan formal maupun non formal dengan cara pembiasaan, keterladan atau praktik langsung,yang diharapkan seseorang dapat menyerap nilai - nilai sehingga dapat membedakan benar atau salah.

\section{Pembelajaran IPS di SD}

Pendidikan IPS adalah penyederhanaan atau adaptasi dari disiplin ilmu-ilmu sosial dan humaniora, serta kegiatan dasar manusia yang diorganisasikan dan disajikan secara ilmiah dan pedagogis/psikologis untuk tujuan pendidikan. ( menurut Supriya, 2009 : 11)Sedangkan menurut Rudy Gunawan (2011: 38) menyatakan bahwa Pembelajaran IImu Pengetahuan Sosial (IPS) di SD hendaknya memperhatikan kebutuhan anak yang berusia antara 6-12 tahun. Anak dalam kelompok usia 7-11 tahun menurut Piaget (1963) berada dalam perkembangan kemampuan intelektual/kognitifnya pada tingkatan kongkret operasional. Mereka memandang dunia dalam keseluruhan yang utuh, dan menganggap tahun yang akan datang sebagai waktu yang masih jauh. Yang mereka pedulikan adalah sekarang (kongkrit), dan bukan masa depan yang belum bisa mereka pahami (abstrak)

Sedangkan di dalam KTSP dirumuskan bahwa IImu Pengetahuan Sosial (IPS) merupakan salah satu mata pelajaran yang diberikan mulai dari SD/MI/SDLB sampai SMP/MTs/SMPLB. IPS mengkaji seperangkat peristiwa, fakta, konsep, dan generalisasi yang berkaitan dengan isu sosial. Pada jenjang SD/MI mata pelajaran IPS memuat materi Geografi, Sejarah, Sosiologi, dan Ekonomi. Melalui mata pelajaran IPS, peserta didik diarahkan untuk dapat menjadi warga negara Indonesia yang demokratis, dan bertanggung jawab, serta warga dunia yang cinta damai.

Adapun tujuan mata pelajaran IPS di SD/MI ditetapkan sebagai berikut: (1) Mengenal konsep-konsep yang berkaitan dengan kehidupan masyarakat dan lingkungannya; (2)Memiliki kemampuan dasar untuk berpikir logis dan kritis, rasa ingin tahu, inkuiri, memecahkan masalah, dan keterampilan dalam kehidupan social; (3)Memiliki komitmen dan kesadaran terhadap nilai-nilai sosial dan kemanusiaan; (4 )Memiliki kemampuan berkomunikasi, bekerjasama dan berkompetisi dalam masyarakat yang majemuk, di tingkat lokal, nasional, dan global.

Dapat disimpulkan bahwa pembelajaran IPS SD mengkaji seperangkat peristiwa, fakta, konsep, dan generalisasi yang berkaitan dengan isu sosial, memuat materi geografi, sejarah, sosiologi, dan ekonomi. Yang dirancang untuk mengembangkan 
pengetahuan, pemahaman, dan kemampuan analisis terhadap kondisi sosial masyarakat dalam memasuki kehidupan bermasyarakat yang dinamis.

\section{Media Audio Visual}

Asra (2007: 5.5) mengemukakan bahwa kata media dalam "media pembelajaran" secara harfiah berarti perantara atau pengantar, sedangkan kata pembelajaran diartikan sebagai suatu kondisi yang diciptakan untuk membuat seseorang melakukan sesuatu kegiatan belajar. Media pembelajaran memberikan penekanan pada posisi media sebagai wahana penyalur pesan atau informasi belajar untukmengondisikan seseorang belajar.

Fungsi dari media pembelajaran juga diungkapkan oleh Asyhar (2011: 29-35) bahwa media pembelajaran memiliki beberapa fungsi yang dijelaskan sebagai berikut. (a) Media sebagai sumber belajar, media pembelajaran berperan sebagai salah satu sumber belajar bagi siswa. (b) Fungsi semantik, melalui media dapat menambah perbendaharaan kata atau istilah. (c) Fungsi manipulatif, adalah kemampuan suatu benda dalam menampilkan kembali suatu benda atau peristiwa dengan berbagai cara, sesuai kondisi, situasi, tujuan dan sasarannya. (d) Fungsi fiksatif, adalah kemampuan media untuk menangkap, menyimpan dan menampilkan kembali suatu objek atau kejadian yang sudah lampau. (e) Fungsi distributive, bahwa dalam sekali penggunaan suatu materi, objek atau kejadian dapat diikuti siswa dalam jumlah besar dan dalam jangkauan yang sangat luas. (f) Fungsi psikologis, media pembelajaran memiliki beberapa fungsi seperti atensi, afektif, kognitif, imajinatif, dan fungsi motivasi. (g) Fungsi sosio kultural, penggunaan media dapat mengatasi hambatan sosial kultural antar siswa.

Setiap jenis pembelajaran memiliki karakteristik yang berbeda satu dengan yang lainnya. Hernawan (2007: 22-34) menjelaskan karakteristik media pembelajaran menurut jenisnya, yaitu: (a) Media visual adalah media yang hanya dapat dilihat. (b) Media audio adalah media yang hanya dapat didengar. (c) Media audio visual merupakan kombinasi audio visual atau biasa disebut media pandang dengar. Sedangkan Pengelompokan jenis-jenis media pembelajaran banyak disampaikan oleh para ahli media pembelajaran, di antaranya Asra (2007: 5.8-5.9) mengelompokkan media pembelajaran menjadi beberapa jenis, yaitu: (a) Media visual yaitu media yang hanya dapat dilihat, seperti foto, gambar dan poster. (b) Media audio yaitu media yang hanya dapat didengar saja seperti kaset audio, MP3, dan radio.(c) Media audio visual yaitu media yang dapat dilihat sekaligus didengar seperti film suara, video, televise dan sound slide. (d) Multimedia adalah media yang dapat menyajikan unsur media secara lengkap seperti suara, animasi, video, grafis dan film.(e) Media realia yaitu semua media nyata yang ada di lingkungan alam, seperti tumbuhan, batuan, air, sawah, dan sebagainya.

Media audio visual merupakan salah satu jenis media pembelajaran yang dapat digunakan dalam proses pembelajaran. Asyhar (2011: 45) mendefinisikan bahwa media audio visual adalah jenis media yang digunakan dalam kegiatan pembelajaran dengan melibatkan pendengaran dan penglihatan sekaligus dalam satu proses atau kegiatan. Pesan dan informasi yang dapat disalurkan melalui media ini dapat berupa pesan verbal dan nonverbal yang mengandalkan baik penglihatan maupun pendengaran. Beberapa contoh media audio visual adalah film, video, program TV dan lain-lain.

Pembelajaran menggunakan teknologi audio visual adalah satu cara menyampaikan materi dengan menggunakan mesin-mesin mekanis dan elektronis untuk menyajikan pesan-pesan audio visual. Arsyad (2011:31) mengemukakan bahwa media audio visual memiliki karakteristik sebagai : (a) Mereka biasanya bersifat linear. (b). Mereka biasanya menyajikan visual yang dinamis. (c) Mereka digunakan dengan cara yang telah ditetapkan sebelumnya oleh perancang/pembuatnya. (d) Mereka 
merupakan gambaran fisik dari gagasan real atau abstrak. (e) Mereka dikembangkan menurut prinsip psikologi behaviorisme dan kognitif. (f) Umumnya mereka berorientasi pada guru dengan tingkat pelibatan interaktif murid yang rendah.

Setiap jenis media yang digunakan dalam proses pembelajaran memiliki kelebihan dan kelemahan begitu pula dengan media audio visual. Arsyad (2011: 49-50) mengungkapkan beberapa kelebihan dan kelemahan media audio visual dalam pembelajaran sebagai berikut. (a.) Kelebihan media audio visual: 1) Film dan vidio dapat melengkapi pengalaman dasar siswa. 2) Film dan vidio dapat menggambarkan suatu proses secara tepat yang dapat disaksikan secara berulang-ulang jika perlu. 3) Di samping mendorong dan meningkatkan motivasi film dan video menanamkan sikapsikap dan segi afektif lainnya. 4) Film dan video yang mengandung nilai-nilai positif dapat mengundang pemikiran dan pembahasan dalam kelompok siswa. 5) Film dan video dapat menyajikan peristiwa yang berbahaya jika dilihat secara langsung. 6) Film dan video dapat ditunjukkan kepada kelompok besar atau kelompok kecil, kelompok yang heterogen maupun homogen maupun perorangan. 7) Film yang dalam kecepatan normal memakan waktu satu minggu dapat ditampilkan dalam satu atau dua menit. (b) Kelemahan media audio visual: 1) Pengadaan film dan video umumnya memerlukan biaya mahal dan waktu yang banyak. 2) Tidak semua siswa mampu mengikuti informasi yang ingin disampaikan melalui film tersebut. 3) Film dan vidio yang tersedia tidak selalu sesuai dengan kebutuhan dan tujuan belajar yang diinginkan, kecuali dirancang dan diproduksi khusus untuk kebutuhan sendiri.

\section{Menanamkan Nilai Karakter Peduli Lingkungan Pada Pembelajaran IPS Melalui Media Audio Visual}

Sebagai seorang pendidik dituntut untuk dapat menanamkan nilai karakter kepada peserta didik. Dikutip dari Muslihin (2007) Kerusakan lingkungan terjadi akibat dari sikap peduli lingkungan yang masih rendah. Hal ini dibuktikan dengan banyaknya manusia yang kurang peduli terhadap lingkungan seperti membuang sampah sembarangan, lahan hijau dijadikan perumahan. Sikap manusia yang akan menentukan baik dan buruknya kondisi suatu lingkungan. Lingkungan yang berada disekeliling kita baik berupa benda-benda hidup seperti tumbuh-tumbuhan, binatang serta benda mati yang harus dijaga keletariannya. Lingkungan seharusnya dapat dipahami sebagai faktor penting dalam membentuk karakter peserta didik. Jika dilingkungan sekolah dibiarkan tembok sekolah kusam, taman tidak terawat serta sampah yang berceceran dimana-mana, kamar kecil yang berbau tidak sedap, lantai yang tidak pernah dipel dan tidak pernah disapu secara rutin akan mempengaruhi suasana belajar siswa. Dari sinilah sangat diperlukan sekali peranan guru dalam memberikan pendidikan karakter peduli lingkungan. Seorang guru dalam memberikan pendidikan karakter seyogyanya tidak hanya memberikan lewat tulisan dan lisan namun harus dibuktikan dengan contoh. Guru jangan hanya memberikan ceramah kepada peserta didik tentang pendidikan karakter, karena pendidikan karakter itu justru dijadikan dengan keteladanan atau contoh nyata.Terlebih didukung usia 6-12 tahun itu lebih cenderung mudah menangkap informasi dengan sesuatu yang kongkrit (nyata).

Dalam pembelajara IPS memuat materi lingkungan sekitar yang berhubungan langsung dalam kehidupan sehari-hari peserta didik. Melalui pembelajaran IPS secara tidak langsung peserta didik dapat belajar langsung tentang lingkungan sekitar. Untuk menunjang pemahaman dan menumnuhkan nilai eduli lingkungan peserta didik maka dapat dibantu dengan media audio visual. Media Audio Visual sangat membantu dalam proses belajar mengajar. 


\section{SIMPULAN}

Bangsa Indonesia begitu sangat memprihatinkan terutama di kalangan remaja hingga anak-anak sebagai generasi penerus bangsa. Semakin merosotnya moral dan karakter anak yang kurang peduli terhadap lingkungan menjadikan Sekolah sebagai sarana utama memperbaiki kepribadian anak. Dengan pembelajaran IPS diharapkan mampu menyelesaikan permasalahan yang di alami bangsa Indonesia saat ini. IPS Sebagai bidang studi dalam pembelajaran bertujuan agar peserta didik peduli terhadap lingkungan sekitar. Dengan bantuan media audio visual memudahkan seorang pendidik dalam menanamkan nilai karakter peduli melalui audio visual.

\section{DAFTAR PUSTAKA}

Amri, Sofan dkk.2011. Implementasi Pendidikan Karakter dalam Pembelajaran. Jakarta: PT Prestasi Pustakaraya

Asra dan sumiati. 2007. Metode Pembelajaran Pendekatan Individual. Bandung:

Rancaekek Kencana.

Aqib, Zainal. 2011. Pendidikan Karakter. Bandung; CV. Yrama Widya

Dede Rosyada.2003. Paradigma Pendidikan Demokratis.Jakarta : Kencana Pernada Media Group

Depdiknas.2003. Undang-undang Nomor 20 Tahun 2003 tentang Sistem Pendidikan Nasional.Jakarta: Depdiknas.

Depdiknas RI.2006. Peraturan Mendiknas Nomor 22 Tahun 2006 Tentang Standar Isi.Jakarta: Depdiknas

Doni Koesoema A. 2007.Pendidik Karakter Strategi Mendidik Anak di Zaman Global.Jakarta: Grasindo

Elfindri dkk. 2012. Pendidikan Karakter Kerangka, Metode, dan Aplikasi untuk Pendidik dan Profesional. Jakarta: Baduose Media

Hafid, anwar, dkk. 2013. Konsep Dasar IImu Pendidikan. Bandung:Alfabeta

Jamal Ma'mur Asmani.2013.Buku panduan internalisasi pendidikan karakter di sekolah.Yogyakarta: DIVA Press

Hernawan, Asep. 2007. Kurikulum Berdiversifikasi. www.kurtek.go.id.edu.

Diakses pada tanggal 17 Mei 2018

KemDiknas.2011.Pedoman Pelaksanaan Pendidikan Karakter: Berdasarkan Pengalaman Di Satuan Pendidikan Rintisan.Jakarta: Badan Penelitian dan Pengembangan. Pusat Kurikulumdan Kompetensi Pedagogik Perbukuan

Maswardi Muhammad Amin.2011. Pendidikan Karakter Anak Bangsa.Jakarta: Baduose

Mason R.1994. Using Communication Media in Open and Flexible Learning, London: Kogan

Muslihin.2017.Pendidikan Karakter Peduli Lingkungan Pada Siswa Sdit Ath Thoriq Gombong Kabupaten Kebumen. IAIN: Skripsi

Mulyasa. 2011. Manajemen Pendidikan Karakter. Jakarta: Bumi Aksara.

Nursid Sumaatmadja. 2007. Konsep Dasar IPS. Jakarta: Universitas Terbuka

Oemar Hamalik .2009. Psikologi Belajar Mengajar. Bandung : Sinar Baru Algensindo

Rifki Afandi. 2011.Integrasi Pendidikan Karakter Dalam Pembelajaran Ips Di Sekolah Dasar.Universitas Muhammadiyah Sidoarjo. PEDAGOGIA Vol. 1, No. 1, Desember 2011: 85-98

Rudy Gunawan. 2011. Pendidikan IPS Filosofi, Konsep, dan Aplikasi. Bandung:

Alfabeta.

Sri Narwanti.2011. Pendidikan Karakter, Yogyakarta: Familia

Sapriya. 2009. Pendidikan IPS. Bandung : PT Remaja Rosdakarya

Suwarsih Madya.2011. Optimalisasi Pemanfaatan TIK untuk MeningkatkanMutu Hakiki Pendidikan. Makalah, Seminar Nasional, Milad UAD XXX.

Thoms Lickona . 2012. Educating for Character.Jakarta : Bumi Aksara 